\title{
The decline of elephant and black rhinoceros in Ethiopia
}

\author{
M. J. Largen and D. W. Yalden
}

From the authors' review of the mammals of Ethiopia, undertaken during the last 14 years, it is clear that Ethiopia's elephants and rhinoceroses have suffered massive declines since the beginning of the century. There are perhaps 9000 elephants left, but poaching for ivory and agricultural encroachment continue to threaten them, and only a few rhinoceroses still survive. Ethiopia has limited resources to protect these remaining animals, and needs help and encouragement from outside its boundaries.

The status of the elephant Loxodonta africana and that of the black rhinoceros Diceros bicomis in Africa continue to give acute concern to conservationists. Concern for the elephant population includes worries about declining range, and whether the ivory trade is taking an exploitable surplus or is itself causing populations to decline (Parker and Martin, 1982, 1983). In a recent report, Western and Vigne (1985) suggested that the total black rhinoceros population of the continent was only 8800 in 1984 , a drop of 40 per cent from the $14,000-15,000$ of 1980 .

The 'Catalogue of the Mammals of Ethiopia' (Largen et al., 1974; Yalden et al., 1976, 1977, 1980,1984 ) clearly demonstrates that nearly all of the larger species have suffered a pronounced depletion of their numbers in Ethiopia during the present century. This decline is most marked in the elephant and black rhinoceros where it has produced a drastic reduction in geographical range (Yalden et al., 1986).

We follow Ansell (1971a) in recognizing three races of elephant in Ethiopia where, until the end of the 19th century, the species remained widespread and comparatively common at altitudes between sea level and about $2500 \mathrm{~m}$ (Figure 1). Since that time, however, numbers have been greatly reduced and the altitudinal range has contracted as the remnant herds have been pushed progressively further back towards the Elephant and black rhino decline in Ethiopia borders of the country. Destruction of natural habitat and harassment by an ever-expanding human population with an ever-increasing demand for land have undoubtedly contributed to this situation, but enormous numbers of elephants have also been killed for profit. The ivory trade was already long established in 1899 when Harrison (1901) reported 1500 tusks being sent to the capital, in the two months preceding his visit, from the southern region of the Ethiopian Rift Valley where the species has since been eradicated. In the central Rift Valley elephants are believed to have been extinguished between 1900 and 1910 (Escherich, 1911). Further north, in the valley of the Awash River where Harrison (1901) encountered herds exceeding 40 animals, Thesiger (1935) believed that only a single individual survived in 1934 . Loxodonta africana knochenhaueri now occurs in Ethiopia only in the Mago Valley, north of Lake Turkana, which held about 60 head (Bolton, 1973), and near the Kenyan border, where the herds are perhaps maintained by recruitment from further south.

West of the Omo River, which flows into the north end of Lake Turkana and marks the boundary between two subspecies, the numbers of $L$. a. oxyotis are likewise sustained to some extent by seasonal migrations from the Sudan. Ethiopia's largest concentration of this race is 103 


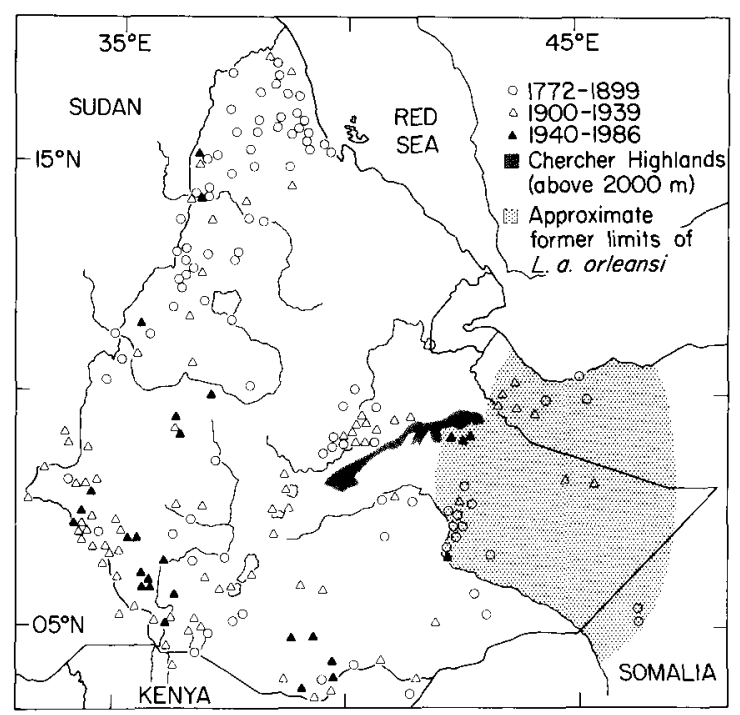

Figure 1. The declining distribution of Loxodonta africana in Ethiopia.

undoubtedly found in the vicinity of the southwestern border, where heavy poaching for meat and ivory gives cause for great concern (Duckworth, 1974). Elephants are still present further north, at least during the wet season, between the Dinder and Balas rivers and in the valley of the Tacazze River (Bolton, 1973). In Eritrea, Leuenberger (1955) reported that herds of 100-200 animals still roamed between the Setit and Gash rivers, but there is little more recent information on the status of the species in this most northern province.

While both oxyotis and knochenhaueri are widely distributed forms, which remain numerous in at least some parts of their geographical ranges, the situation of $L$. a. orleansi is much more precarious. This very distinctive subspecies has been recorded only from northern Somalia, where it has become extinct since 1928 (Hunt, 1951; Funaioli and Simonetta, 1966), and from adjacent areas of Ethiopia between the Chercher Highlands in the north and the Webi Shebeli to the south. The only surviving representatives of this race are found south of the city of Harar where they appear to undertake seasonal migrations along the Errer, Dacata and Fafan Valleys, between the headwaters of these rivers and the environs of Ime on the Webi Shebeli (Bolton, 1973). At least 130 individuals 104 were present in this area in 1967 (Ingersol, 1968), but the most recent count recorded a minimum of only 60 head (J. G. Stephenson, in litt., 1978), which may well indicate that this elephant is continuing to decline; certainly the recent history of the species in Ethiopia gives no cause for complacency. The range of this population is included within the Harar Elephant Sanctuary, which means that the animals may not legally be shot, even under licence, but they receive little additional protection due to the lack of resources presently available for this purpose. Since the beasts are highly unpopular with local farmers, they must be considered to be very much at risk, and effective conservation measures are urgently required if $L$. a. orleansi is to be secured from the threat of eventual and total extinction.

In response to a first draft of this paper, Ato Abdu Mahamued of the Ethiopian Wildlife Conservation Organization (EWCO) has summarized for us the current estimates of elephant populations in Ethiopia (in litt., 4 November 1986). These suggest a total population of around 9000 animals, including 300 L. a. orleansi (Table 1). While these figures are higher than some of those cited earlier, they do not necessarily indicate that populations are increasing; these are estimates for total populations, whereas the earlier figures, particularly for $L$. a. orleansi, are direct counts made on specific occasions. For $L$. a. oxyotis and L. a. knochenhaueri, migratory movements across international frontiers also account for some genuine variation in counts. Ato Abdu reports that poaching is still a problem, and that some 500 tusks have been confiscated over the last six years; these are estimated to be perhaps one-third of the numbers actually poached. Agricultural encroachment into elephant habitat also continues to threaten some populations, with resettlement from the drought areas of northern Ethiopia in the Gambella area and coffee plantations being extended around Mizan Teferi. The EWCO hopes to finance stronger protection for conservation areas by opening new controlled hunting areas to maximize the income from sport hunting.

It is to be hoped that the few elephant herds that still remain in Ethiopia will not recapitulate the

Oryx Vol 21 No 2, April 1987 
dismal history of the black rhinoceros, now reduced to a level where conservation has almost ceased to be a realistic proposition. Formerly widespread and evidently quite common in some areas, this species occupied semi-desert and savanna habitats at elevations of approximately 400-2300 m, being, like the elephant, confined to the foothills of the central plateaux (Figure 2). Its range probably remained little altered until about 1900 , but thereafter the populations suffered a collapse of devastating rapidity and proportions. The black rhinoceros is believed to have been extinct in the central Rift Valley of Ethiopia by 1909 (Escherich, 1911) and in most of the north-western part of the country 10 years later (Zedlitz and Trützschler, 1919). There seems to have been a population crash in the Ogaden region of eastern Ethiopia at much the same time, Drake-Brockman (1909) apparently being the last traveller to encounter the species in this area, although small numbers possibly survived here, as in northern Somalia, until the 1930s (Turner, 1937; Hunt, 1951; Funaioli and Simonetta, 1966). In the Awash Valley rhinoceroses perhaps lingered until about 1940, if an anonymous (1940) report is accepted, but they must have disappeared very soon afterwards. Sport hunting (e.g. Ghika, 1898 ) seems to have played a large part in these rapid declines.

At the present time, the only known survivors in Ethiopia are a few individuals reported in the vicinity of the Omo River (Urban and Brown, 1968; Bolton, 1973), along the border with

Table 1. Estimates of the recent elephant population in Ethiopia (EWCO figures, Abdu Mahamued, pers. comm.)

L. a. knochenhauer

Mago NP, Tama Reserve and Murle

Borana

L. a. oxyotis

Omo NP

Akobo R.-Mizan Teferi area

Metehel-Dabus R.

Gash R. -Setit R.

L. a. orleansi

Harar-Wabi Shebelli R.

Total Ethiopia

c9000

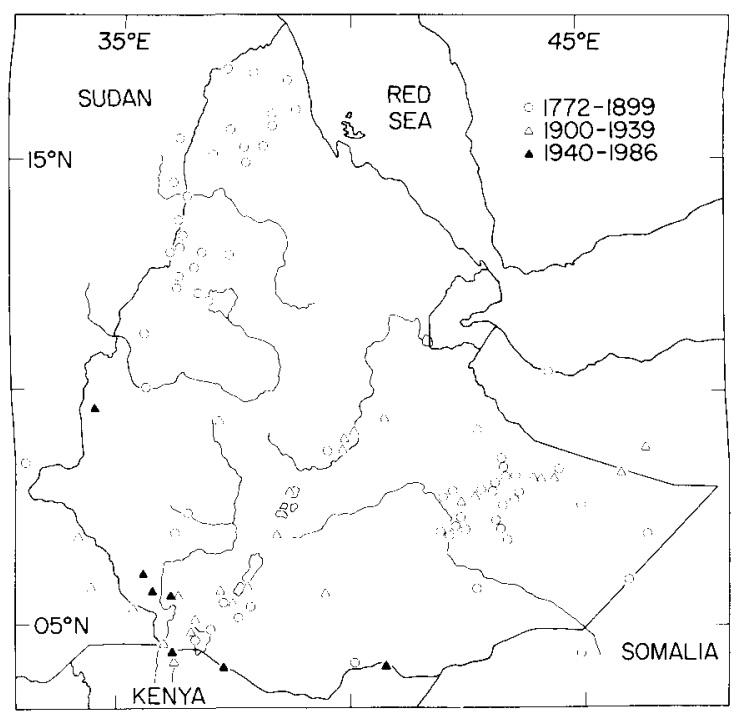

Figure 2. The declining distribution of Diceros bicornis in Ethiopia.

Kenya, and close to the Sudan border in the area of the Dabus River (Ansell, 1971b). The assessments by Western and Vigne (1985) of 20 in 1980 and 10 in 1984 seem both very optimistic and spuriously accurate. The situation is no less bleak in Somalia, where D. bicomis was almost extinct 20 years ago; Funaioli and Simonetta (1966) estimated that fewer than 50 individuals then remained, mostly in the extreme south of the country. In Sudan the species has become very scarce, and it has declined sharply in Kenya (Western and Vigne, 1985).

It may be true that the survival of such large mammals is almost incompatible with the requirements of a developing country, and that, like most big game, they can be preserved for the future only in protected areas specially set aside for the purpose (Dorst and Dandelot, 1972). Fortunately, at least a few nations on the African continent have the resources to provide such sanctuaries, but Ethiopia is in a less enviable position and the few national parks now established in this country have yet to be fully secured, staffed and equipped. The fact that the Omo National Park harbours a small number of elephants and black rhinoceroses does not, in itself, guarantee that the country will not ultimately be further impoverished by the loss of one or both of these species. Hillman (1986) has 
recently drawn attention to the commendable efforts made by the EWCO, and has requested that more support be given by outside conservation bodies. In supporting both his commendation and his request, we would like to draw particular attention to the plight of Loxodonta africana orleansi.

\section{Acknowledgments}

The preparation of Figures 1 and 2 would have been impossible without the contribution of numerous travellers and research workers who have published their observations during the past 200 years. We gratefully acknowledge the assistance of Dr D. Kock in the extraction of these data from the literature and, for the provision of additional information, we thank Dr J. S. Ash, Mr R. O. S. Clarke, Dr J. C. Hillman, Ato Abdu Mahamued and Mr J. G. Stephenson.

\section{References}

Anon. 1940. Segnalazione di Rinoceronti in Dancalia. Boll. Idrobiol. Cacc. Pesca Afr. orient. ital. 1 (1), 155-156.

Ansell, W.F.H. 1971a. Order Proboscidea. In The Mammals of Africa: An Identification Manual (Eds J. Meester and $\mathrm{H}$. W. Setzer), Part 11, pp. 1-5. Smithsonian Institute Press, Washington.

Ansell, W.F.H. 1971b. Order Perissodactyla. In The Mammals of Africa: An Identification Manual. (Eds J. Meester and $H$. W. Setzer), Part 14, pp. 1-4 Smithsonian Institute Press, Washington.

Bolton, M. 1973. Notes on the current status and distribution of some large mammals in Ethiopia (excluding Eritrea). Mammalia, 37 (4), 562-586.

Dorst, J. and Dandelot, P. 1972. A Field Guide to the Larger Mammals of Africa, 2nd edn. Collins, London.

Drake-Brockman, R.E. 1909. The fauna of Abyssinia. J. Soc. Preserv. Fauna Emp. 5, 110-113.

Duckworth, F.W. 1974. Gambella 1973--a wildlife report Walia, 5, 9-11.

Escherich, G. 1911. Von Djibuti zum Rudolf-See. Ber senckenb. naturf. Ges. 42, 283-308.

Funaioli, U. and Simonetta, A.M. 1966. The mammalian fauna of the Somali Republic: status and conservation problems. Monitore zool. ital. Suppl. 74, 285-347.

Ghika, N. 1898. Cinq Mois au Pays de Somalis. Georg \& Co., Bale and Geneva.

Harrison, J.J. 1901. A journey from Zeila to Lake Rudolf Geogr. J. 18, 258-275.

Hillman, J.C. 1986. Conservation in Bale Mountains
National Park, Ethiopia. Oryx, 20, 89-94.

Hunt, J.A. 1951. A General Survey of the Somaliland Protectorate 1944-1950. Waterlow \& Sons, London.

Ingersol, R.H. 1968. The ecological stratification of mammals in the eastern Chercher Highlands of Harar Province, Ethiopia. PhD Thesis. Oklahoma State University.

Largen, M.J., Kock, D. and Yalden, D.W. 1974. Catalogue of the mammals of Ethiopia. 1. Chiroptera. Monitore zool. ital. (NS) Suppl. 5, 221-298.

Leuenberger, H. 1955. Athiopien, Kaiserreich seit Salomon. Stauffacher Verlag, Zürich.

Parker, I.S.C. and Martin, E.B. 1982. How many elephants are killed for the ivory trade? Oryx, 16, 235-239.

Parker, I.S.C. and Martin, E.B. 1983. Further insight into the international ivory trade. Oryx, 17, 194-200.

Thesiger, W. 1935. The Awash River and the Aussa Sultanate. Geogr. J. 85 (1), 1-23.

Turner, D.P. 1937. Some notes on the game of the British Somaliland boundary. J. Soc. Preserv. Fauna Emp. (NS) 31, 56-62.

Urban, E.K. and Brown, L.H. 1968. Wildlife in an Ethiopian valley. Oryx, 9 (5), 342-353.

Western, D. and Vigne, L. 1985. The deteriorating status of African rhinos. Oryx, 19, 215-220.

Yalden, D.W., Largen, M.J. and Kock, D. 1976. Catalogue of the mammals of Ethiopia. 2. Insectivora and Rodentia. Monitore zool. ital. (NS) Suppl. 8, 1-118.

Yalden, D.W., Largen, M.J. and Kock, D. 1977. Catalogue of the mammals of Ethiopia. 3. Primates. Monitore zool. ital. (NS) Suppl. 9, 1-52.

Yalden, D.W., Largen, M.J. and Kock, D. 1980. Catalogue of the mammals of Ethiopia. 4. Carnivora. Monitore zool. ital. (NS) Suppl. 13, 169-272.

Yalden, D.W., Largen, M.J. and Kock, D. 1984. Catalogue of the mammals of Ethiopia. 5. Artiodactyla. Monitore zool. ital. (NS) Suppl. 19, 67-221.

Yalden, D.W., Largen, M.J. and Kock, D. 1986. Catalogue of the mammals of Ethiopia. 6. Perissodactyla, Proboscidea, Hyracoidea, Lagomorpha, Tubulidentata, Sirenia and Cetacea. Monitore zool. ital. (NS) Suppl. 21, 31-103.

Zedlitz, O. and Truitzschler, O. 1919. Jagdbare Säugetiere in Eritrea und Nordwest-Abessinien. Biologisches und Jagdliches aus meinen Reisetagebüchern. Wild $u$. Hund, 25 (30), 375-377; (31), 387-388; (33), 418-419; (35), $441-443 ; \quad(36), \quad 455-457 ; \quad(37), \quad 468-469 ; \quad(38)$, $480-482$.

M. J. Largen, Liverpool Museum, William Brown Street, Liverpool L3 8EN, UK (formerly Department of Biology, University of Addis Ababa).

D. W. Yalden, Department of Zoology, University of Manchester, Manchester M13 9PL, UK. 